\title{
Effect of Herbal Antimicrobials on Bacterial Strains of Foods of Vegetable and Animal Origin
}

\author{
Bhoj R. Singh", Dharmendra K. Sinha and Vinodh Kumar O. R \\ ICAR-Indian Veterinary Research Institute, Izatnagar-243122, India
}

"Correspondence to:

Bhoj R Singh

Act. Head of Division of Epidemiology

Indian Veterinary Research Institute

Izatnagar-243122, India

Tel: +91-8449033222

E-mail: brs1762@ivri.res.in

Received: March 07, 2016

Accepted: July 19, 2016

Published: July 21, 2016

Citation: Singh BR, Sinha DK, Kumar VOR. 2016. Effect of Herbal Antimicrobials on Bacterial Strains of Foods of Vegetable and Animal Origin. J Food Chem Nanotechnol 2(3): 115-123.

Copyright: : (c) 2016 Singh et al. This is an Open Access article distributed under the terms of the Creative Commons Attribution 4.0 International License (CC-BY) (http://creativecommons. org/licenses/by/4.0/) which permits commercial use, including reproduction, adaptation, and distribution of the article provided the original author and source are credited.

Published by United Scientific Group

\section{Abstract}

At the face of emergence of multiple antibiotic resistant strains, herbal antimicrobials are looked as the future drugs for therapeutics, and also as food preservative. This study was undertaken to understand the antimicrobial activity of some selected herbal preparations on bacteria of food origin. In the study 464 (254 from foods of vegetable origin, 134 from foods of animal origin, 14 from food handlers, 62 reference) strains belonging to more than 104 species of 33 genera of Gram negative (194) bacteria (GNB) and Gram positive (270) bacteria (GPB) were tested for their sensitivity to methanolic extract of Eupatorium odoratum (EOME), methanolic extract of Ageratum conyzoides (ACME), methanolic extract of Zanthoxylum rhetsa seed coat (ZRME), lemon grass (Cymbopogon citratus) oil (LGO), sandalwood (Santalum album) oil (SWO), patchouli (Pogostemon cablin) oil (PO) and agarwood (Aquilaria crassna) oil (AO) through disc diffusion method. Besides, minimum inhibitory concentration (MIC) of different herbal preparations was determined for test strains using agar-well dilution method. Sandalwood oil inhibited maximum number of strains (50.5\%) followed by LGO (45.9\%), EOME (43.8\%), ACME (40.4\%), PO (38\%), ZEME (19.6\%) and AO (17.5\%). Enterobacteriaceae strains in general showed more resistance to herbal antimicrobials than strains of any other family. The MIC for different herbal preparations varied for different strains from $1 \mu \mathrm{g} \mathrm{mL} L^{-1}$ to $>16.384 \mathrm{mg} \mathrm{mL}^{-1}$. The study indicated that herbal antimicrobials being edible and acceptable since ages can be an option for use in foods to control spoilage and choice may depend on type of microbe causing the problem in the specific food unit.

\section{Keywords}

Meat, Milk, Food handlers, Eupatorium odoratum, Ageratum conyzoides, Zanthoxylum rhetsa, Cymbopogon citratus, Santalum album, Pogostemon cablin, Aquilaria crassna

\section{Introduction}

Use of herbal components in food for food preservation is known since long and many phytochemicals have been used for the purpose [1,2]. Besides, phytochemicals strongly affect the odour and flavour thus the taste [1]. Phytochemicals are not equally active on different microbes similar to antibiotics thus general recommendations may not be possible for their judicious use [3]. Moreover, different herbal antimicrobials impart different flavours and odours thus are not equally acceptable in different communities [2]. Therefore, many different phytochemicals have been studied for their antimicrobial activities in different regions mainly based on the availability and ethnic use in the society. Similar to emergence of antibiotic drug resistance in strains of clinical and nonclinical origin herbal drug resistance is also now steadily gaining acceptance for 
its emergence [3] and it is important to monitor the effect of herbal antimicrobials in environmental, food and clinical strains of potential food spoilage and pathogenic bacteria. This study was undertaken to study the antimicrobial potential of
Eupatorium odoratum, Ageratum conyzoides, Zanthoxylum rhetsa, Cymbopogon citrates, Santalum album, Pogostemon cablin, and Aquilaria crassna ingredients often used for culinary purpose in India and having antimicrobial potential $[4,5]$. Therefore,

Table 1: Sensitivity of bacterial strains to different herbal antimicrobials tested using disc (containing $1 \mathrm{mg}$ of active ingredient/ disc) diffusion assay on Mueller Hinton agar (MHA) for non-fastidious bacteria, MHA with lysed sheep blood (5\%) for fastidious bacteria (Bordetella, Brucella, Campylobacter, Listeria, Pasteurella, Streptococcus).

\begin{tabular}{|c|c|c|c|c|c|c|c|c|c|}
\hline $\begin{array}{l}\text { Genus of the bacteria } \\
\text { tested (Numbers) }\end{array}$ & $\begin{array}{l}\text { Species (source, number) of strains } \\
\text { tested }\end{array}$ & $\mathbf{N}$ & $\begin{array}{l}\text { Number } \\
\text { of strains } \\
\text { sensitive to }\end{array}$ & & & & & & \\
\hline & & & $\begin{array}{l}\mathrm{EO} \\
\mathrm{ME}\end{array}$ & $\begin{array}{l}\mathrm{AC} \\
\mathrm{ME}\end{array}$ & $\begin{array}{l}\mathrm{LG} \\
\mathrm{O}\end{array}$ & $\begin{array}{l}\text { SW } \\
\mathrm{O}\end{array}$ & $\mathrm{PO}$ & $\begin{array}{l}\mathrm{ZR} \\
\mathrm{ME}\end{array}$ & $\mathrm{AO}$ \\
\hline Acinetobacter (2) & A. calcoaceticus (milk, 2) & 2 & NT & NT & 0 & 0 & 0 & NT & 0 \\
\hline Aerococcus (1) & Aerococcus spp. (milk 1) & 1 & NT & NT & 0 & 0 & 0 & NT & 0 \\
\hline \multirow[t]{5}{*}{ Aeromonas (12) } & A. eucranopbila (fish 4) & 4 & NT & NT & 4 & NT & 0 & NT & NT \\
\hline & A. hydrophila (fish 2) & 2 & NT & NT & 2 & NT & 0 & NT & NT \\
\hline & A. media (fish 4) & 4 & NT & NT & 4 & NT & 0 & NT & NT \\
\hline & A. salmonicida (fish 1) & 1 & NT & NT & 1 & NT & NT & NT & NT \\
\hline & A. veronii (fish 1) & 1 & NT & NT & 1 & NT & 0 & NT & 0 \\
\hline Alcaligenes (1) & A. faecalis (milk 1) & 1 & NT & NT & 0 & 0 & 0 & NT & 0 \\
\hline \multirow[t]{13}{*}{ Bacillus (94) } & B. anthracoides (Axone 3) & 3 & 2 & 3 & 3 & 3 & 3 & 1 & NT \\
\hline & B. badius (Axone 7) & 7 & 1 & 5 & 7 & 5 & 5 & 4 & NT \\
\hline & B. brevis (Axone 4) & 4 & 2 & 3 & 3 & 3 & 3 & 3 & NT \\
\hline & B. circulans (Axone 4) & 4 & 1 & 4 & 4 & 4 & 4 & 3 & NT \\
\hline & B. coagulans (Axone 30 ) & 30 & 9 & 12 & 26 & 27 & 26 & 5 & 2 \\
\hline & B. laterosporus (Axone 1) & 1 & 1 & 1 & 1 & 1 & 1 & 0 & 0 \\
\hline & B. lentus (Axone 8) & 8 & 2 & 6 & 8 & 6 & 6 & 4 & 1 \\
\hline & B. licheniformis (Axone 6) & 6 & 0 & 0 & 0 & 0 & 0 & 0 & 0 \\
\hline & B. marcerans (Axone 4, milk 1) & 5 & 1 & 4 & 5 & 4 & 2 & 2 & 1 \\
\hline & B. mycoides (Axone 2) & 2 & 2 & 1 & 2 & 2 & 2 & 0 & 2 \\
\hline & B. pentothenticus (Axone 16) & 16 & 2 & 15 & 15 & 15 & 12 & 15 & NT \\
\hline & B. stearothermophilus (Axone 5) & 5 & 5 & 3 & 5 & 5 & 5 & 0 & 3 \\
\hline & B. subtilis (Axone 3) & 0 & 3 & 3 & 1 & 3 & 3 & 0 & 1 \\
\hline Bordetella (1) & B. bronchiseptica (ref 1, MTCC6838) & 1 & 0 & 0 & 0 & 0 & 0 & NT & 0 \\
\hline Brucella (3) & B. abortus (ref 3, S19, S99, B19) & 4 & 0 & 2 & 2 & 2 & 2 & NT & 0 \\
\hline Budvicia (1) & B. aquatica (fish 1) & 1 & $\mathrm{Nt}$ & NT & 1 & NT & 0 & NT & NT \\
\hline \multirow[t]{3}{*}{ Burkholderia (4) } & B. cepacia (ref 1, MTCC438) & 1 & 1 & 1 & 1 & 1 & 0 & NT & 1 \\
\hline & B. gladioli (ref ,1 MTCC 1888), & 1 & 0 & 0 & 0 & 0 & 0 & NT & 0 \\
\hline & $\begin{array}{l}\text { B. pseudomallei (ref 2, MTCC7183, } \\
\text { MTCC7259) }\end{array}$ & 2 & 0 & 0 & 0 & 0 & 0 & NT & 0 \\
\hline Campylobacter (4) & C.jejunii (ref 4, CJ1-4) & 4 & 0 & 0 & 0 & 0 & 0 & 0 & 0 \\
\hline \multirow[t]{2}{*}{ Citrobacter (7) } & C. diversus (Axone 1) & 1 & 0 & 0 & 0 & 0 & 0 & 1 & 0 \\
\hline & C. freundii (fish 3, muffen 3) & 6 & 0 & 0 & 0 & 0 & 0 & 0 & 1 \\
\hline Edwardsiella (1) & E. $\operatorname{tarda}($ fish 1) & 1 & $\mathrm{Nt}$ & NT & 0 & NT & 0 & NT & NT \\
\hline Enterobacter (23) & $\begin{array}{l}\text { E. agglomerans (Axone 11, milk 4, ref } \\
1 \text { RAVI) }\end{array}$ & 16 & 0 & 4 & 7 & 0 & 4 & 2 & 0 \\
\hline
\end{tabular}




\begin{tabular}{|c|c|c|c|c|c|c|c|c|c|}
\hline & E. amnigenus (Axone 1, muffen 3 ) & 4 & 0 & 0 & 0 & 1 & 0 & 0 & 2 \\
\hline & E. gregoviae (Axone 3), & 3 & 0 & 0 & 0 & 0 & 0 & 0 & NT \\
\hline \multirow[t]{12}{*}{ Enterococcus (70) } & E. asacchrolyticus (Axone 1) & 1 & NT & 1 & 1 & 1 & 1 & 0 & NT \\
\hline & E. avium (Axone 4) & 4 & 0 & 0 & 2 & 1 & 0 & 0 & NT \\
\hline & E. caecorum (Axone 28) & 28 & 11 & 2 & 9 & 14 & 9 & 2 & 2 \\
\hline & E. casseliflavus (Axone 3) & 3 & 0 & 1 & 2 & 2 & 1 & 0 & NT \\
\hline & E. dispar (Axone 6) & 6 & 4 & 1 & 2 & 3 & 2 & 0 & 0 \\
\hline & E. faecalis (Axone 3) & 3 & 0 & 1 & 1 & 1 & 0 & 0 & NT \\
\hline & E. faecium (skin 1) & 1 & NT & NT & 0 & 1 & 0 & 0 & NT \\
\hline & E. gallinarum (Axone 6) & 6 & 0 & 1 & 0 & 0 & 0 & 0 & NT \\
\hline & E. hirae (Axone 7) & 7 & 0 & 1 & 2 & 2 & 1 & 0 & NT \\
\hline & E. malodoratus (Axone 3) & 3 & 2 & 0 & 0 & 1 & 1 & 0 & 0 \\
\hline & E. mundatii (Axone 3) & 3 & 2 & 0 & 2 & 1 & 1 & 0 & $\mathrm{Nt}$ \\
\hline & E. raffinosus (Axone 5) & 5 & 2 & 1 & 0 & 1 & 0 & 0 & 0 \\
\hline Erwinia (3) & $\begin{array}{l}\text { E. chrysanthemi (fish 1, ref 2, E7300, } \\
\text { E7300/1) }\end{array}$ & 3 & 0 & 0 & 0 & 0 & 0 & NT & 0 \\
\hline \multirow[t]{2}{*}{ Escherichia (25) } & E. blattae (fish 3) & 3 & NT & NT & 2 & NT & 0 & NT & NT \\
\hline & $\begin{array}{l}\text { E. coli (Axone 8, milk 9, ref 5, E382, } \\
\text { E382/1, YP1, YP2, Eca) }\end{array}$ & 22 & 1 & 0 & 5 & 0 & 1 & 0 & 0 \\
\hline Hafnia (2) & H. alvei (Axone1, milk 1) & 2 & & 1 & 0 & 0 & 1 & 0 & 0 \\
\hline \multirow[t]{2}{*}{ Klebsiella (15) } & K. oxytoca (fish 1$)$ & 1 & NT & NT & 1 & NT & 0 & NT & NT \\
\hline & $\begin{array}{l}\text { K. pneumoniae (Axone 8, fish 1, milk } \\
\text { 4, muffen 1) }\end{array}$ & 14 & 0 & 2 & 4 & 1 & 2 & 1 & 1 \\
\hline Lactobacillus (1) & L. acidophilus (Axone 1) & 1 & NT & NT & 1 & 1 & 1 & 1 & NT \\
\hline Leminorella (1) & L. ghrimontii (fish 1) & 1 & NT & NT & 0 & 0 & 0 & NT & NT \\
\hline Listeria (1) & L. monocytogenes (ref $1, \mathrm{MTCC} 839)$ & 1 & 0 & 1 & 1 & 1 & 0 & NT & 1 \\
\hline Micrococcus (2) & M. agilis (Axone 2) & 2 & 2 & 1 & 1 & 2 & 1 & 0 & NT \\
\hline \multirow[t]{2}{*}{ Pasteurella (3) } & P. canis (milk 1) & 1 & NT & NT & 1 & 0 & 0 & 0 & 0 \\
\hline & P. multocida (ref 2, P52, Soron) & 2 & 2 & 1 & 2 & 2 & 2 & 0 & 1 \\
\hline Pediococcus (1) & Pediococcus spp. (milk 1) & 1 & 0 & 0 & 0 & 0 & 0 & NT & 0 \\
\hline \multirow[t]{4}{*}{ Proteus (20) } & P. mirabilis (Axone 7, fish 1) & 8 & NT & 0 & 4 & 0 & 0 & 0 & NT \\
\hline & P. myxofaciens (Axone 1) & 1 & NT & 0 & 1 & 0 & 0 & 0 & NT \\
\hline & P. penneri (Axone 5, fish 2) & 7 & NT & 0 & 1 & 0 & 0 & 0 & NT \\
\hline & P. vulgaris (Axone 3 , fish 1 ) & 4 & NT & 0 & 0 & 0 & 0 & 0 & NT \\
\hline Providencia (5) & P. rettgeri (Axone 5) & 5 & & 0 & 0 & 0 & 0 & 0 & NT \\
\hline \multirow[t]{3}{*}{ Pseudomonas (30) } & P. aeruginosa (Axone 22, milk 2) & 24 & 1 & NT & 15 & 9 & 20 & 9 & 1 \\
\hline & P. fluorescens (fish 3, milk 1) & 4 & NT & NT & 0 & 0 & 0 & NT & 0 \\
\hline & P. pseudoalcaligenes (fish 2) & 2 & NT & NT & 2 & 0 & 0 & NT & NT \\
\hline Raoultella & R. terrigena (milk 1$)$ & 1 & NT & NT & 0 & 0 & 0 & NT & 0 \\
\hline Salmonella & $\begin{array}{l}\text { S. enterica ssp. enterica serovars (Ref } \\
27 \text { from NSC) }\end{array}$ & 27 & 0 & 0 & 4 & 2 & 2 & 2 & 1 \\
\hline Serratia & S. plymuthica (muffen 1) & 1 & 0 & 0 & 0 & 0 & 0 & 0 & 0 \\
\hline Staphylococcus (80) & $\begin{array}{l}\text { S. aureus (skin 4, buffen 2, chevon 5, } \\
\text { ref } 3 \text {, ATCC43300, ATCC29213, } \\
\text { ATCC700699), }\end{array}$ & 12 & NT & NT & 4 & 10 & 8 & 2 & 1 \\
\hline \multirow{3}{*}{ Streptococcus (20) } & S. auricularis (chevon 2) & 2 & NT & NT & 0 & 1 & 1 & 0 & 0 \\
\hline & S. caprae (chevon 1) & 1 & NT & NT & 1 & 1 & 1 & 0 & 0 \\
\hline & S. capitis (buffen 4, milk 1 ) & 5 & 0 & 0 & 3 & 4 & 1 & NT & 1 \\
\hline
\end{tabular}




\begin{tabular}{|c|c|c|c|c|c|c|c|c|c|}
\hline & S. caseolyticus (milk 1 , chevon 1 ) & 2 & NT & NT & 1 & 2 & 0 & 1 & 0 \\
\hline & $\begin{array}{l}\text { S. chromogenes ( chevon } 3 \text {, buffen } 1 \text {, } \\
\text { milk } 1 \text { ) }\end{array}$ & 5 & NT & NT & 2 & 5 & 2 & 1 & 2 \\
\hline & $\begin{array}{l}\text { S. epidermidis ( chevon 7, milk 1, skin } \\
\text { 3, ref 2, BM, MTCC 449) }\end{array}$ & 13 & 1 & 1 & 4 & 12 & 6 & 4 & 3 \\
\hline & S. felis (chevon 1) & 1 & NT & NT & 0 & 0 & 1 & 0 & 0 \\
\hline & S. haemolyticus (chevon 2, milk 1 ) & 3 & NT & NT & 3 & 3 & 3 & 0 & 0 \\
\hline & S. hominis (chevon 2) & 2 & NT & NT & 1 & 2 & 1 & 0 & 0 \\
\hline & S. hyicus (buffen 3, milk 1) & 4 & 0 & 0 & 2 & 3 & 2 & NT & 1 \\
\hline & S. intermedius (chevon 6) & 6 & NT & NT & 5 & 6 & 5 & 0 & 2 \\
\hline & S. lentus (buffen 2) & 2 & NT & NT & 1 & 2 & 1 & NT & 1 \\
\hline & S. scheferi (chevon 1) & 1 & NT & NT & 1 & 1 & 1 & 1 & 0 \\
\hline & S. sciuri (Axone 12, skin 3) & 15 & 7 & 4 & 3 & 9 & 6 & 0 & 0 \\
\hline & S. warneri (milk 1) & 1 & NT & NT & 1 & 1 & 1 & NT & NT \\
\hline & S. xylosus (Axone 2, chevon 1) & 3 & 0 & 2 & 0 & 3 & 1 & 0 & 0 \\
\hline & S. agalactiae (milk 3, ref $1, \mathrm{CJ} 1$ ) & 4 & 1 & 1 & 1 & 2 & 1 & 1 & 1 \\
\hline & S. bovis (milk 3) & 3 & NT & NT & 3 & NT & 3 & NT & 0 \\
\hline & S. dysgalactiae (ref 2, CB, CJ3) & 2 & 0 & 0 & NT & 1 & 0 & 0 & 0 \\
\hline & S. equi (milk 1, ref 1 MTCC3522) & 2 & 1 & 1 & 1 & 2 & 2 & NT & 1 \\
\hline & S. gallinarum (skin 1) & 1 & NT & NT & 1 & 1 & 1 & 1 & NT \\
\hline & S. intestinalis (milk 5) & 5 & 2 & 2 & 2 & 3 & 0 & NT & 1 \\
\hline & S. pyogenes (milk 1, skin 1, ref 1, CJ4) & 3 & 1 & 1 & 2 & 0 & 0 & 0 & 1 \\
\hline Yersinia & Y. enterocolitica (ref 1 MTCC 3100$)$ & 1 & 0 & 0 & 0 & 0 & 0 & NT & 0 \\
\hline $\begin{array}{l}\text { Number of total strains } \\
\text { tested }\end{array}$ & & & 162 & 282 & 460 & 404 & 460 & 331 & 206 \\
\hline Number of strains sensitive & & & 71 & 114 & 211 & 204 & 175 & 65 & 36 \\
\hline $\begin{array}{l}\text { Percent (\%) of strains } \\
\text { sensitive }\end{array}$ & & & 43.8 & 40.4 & 45.9 & 50.5 & 38.0 & 19.6 & 17.5 \\
\hline
\end{tabular}

$\mathrm{N}$, number of strains tested; NT, not tested; EOME, methanolic extract of Eupatorium odoratum; $\quad$ ACME, methanolic extract of Ageratum conyzoides; LGO, lemon grass (Cymbopogon citrartus) oil; SWO, sandalwood (Santalum album) oil; PO, patchouli (Pogostemon cablin) essential oil; ZRME, methanolic extract of seed carps of Zanthoxylus rhetsa, AO, agarwood (Aquilaria crassna) oil; NSC, National Salmonella centre (Vet) at Indian Veterinary Research Institute, Izatnagar; MTCC, microbial type culture collection, Chandigarh; ATCC, American type culture collection; ref, reference strains procured from VTCC (Veterinary type culture collection, Indian Veterinary Research Institute) or MTCC and other reference labs, the culture number of reference labs are given for their identity in the repository.

antimicrobial potential testing of the herbal preparations was not only restricted to reference bacterial strains but strains isolated from food handlers and foods of animal and vegetable origin were tested.

\section{Materials and Methods}

\section{Bacterial strains}

A total of 464 strains belonging to more than 104 species of 33 genera (Table 1) available in the laboratory repository in glycerol stocks were revived as per standard protocol and tested for their identity and purity using morphological, growth and biochemical characteristics [6] and stored on brain heart infusion agar slants for the period of the study [6]. Of the 464 strains tested 254 were from fermented soybean product (Axone) consumed in North East India, 12 were isolated from buffen (buffalo meat), 32 from chevon (goat meat), 49 from buffalo milk, 33 from fish, 8 from muffen (mithun, Bos frontalis, meat), 14 from hand swabs of milk and meat vendors, and 62 reference strains of either American type culture collection (ATCC), Microbial type culture collection centre (MTCC), National Salmonella centre (NSC), Brucella Referral centre, or from Veterinary type culture collection (VTCC) of the Institute (Table 1).

\section{Herbal antimicrobials}

Methanolic extract of Eupatorium odoratum fresh leaves (EOME) collected during February and March, methanolic extract of Ageratum conyzoides fresh leaves (ACME) collected during October and November, methanolic extract of Zanthoxylum rhetsa seed coat (ZRME) purchased from Medziphhema market (Nagaland) in December were prepared in the laboratory as described earlier [7]. Briefly, the 
herbs were cleaned to remove any dirt and dried in shade for 5-7 days and pounding to powder. A $250 \mathrm{~g}$ of powder was mixed with $500 \mathrm{ml}$ of methanol (99.9\%, Merck India Ltd.) in a $2 \mathrm{~L}$ conical flask and allowed to stand overnight on a rotary shaker $(50 \mathrm{rpm})$ at $25^{\circ} \mathrm{C}$. Next morning, the flask contents were filtered through glass wool and filtrate was allowed to dry in crystallization bowls at $45^{\circ} \mathrm{C}$ for $4-6 \mathrm{~h}$ or till the entire methanol got evaporated. The dry contents were weighed and again dissolved in methanol to contain $50 \mathrm{mg}$ in one $\mathrm{mL}$ of solution (EOME). $20 \mu \mathrm{L}$ of solution containing $1 \mathrm{mg}$ of dry weight of methanolic extract was poured on to individual 6 $\mathrm{mm}$ sterile discs and discs were dried in air and stored at $4{ }^{\circ} \mathrm{C}$ [8].

Lemon grass (Cymbopogon citratus) oil (LGO), sandalwood (Santalum album) oil (SWO), patchouli (Pogostemon cablin) oil (PO) and agarwood (Aquilaria crassna) oil (AO) were purchased from Nagaland Fragrance Ltd., Dimapur and discs were prepared as described earlier to contain $1 \mathrm{mg}$ of oil per disc [8]. All discs were stored at $4-8{ }^{\circ} \mathrm{C}$ throughout the period of study.

The amount of herbal antimicrobial in each disc $(1 \mathrm{mg})$ was decided on the basis of previous reports indicating that most of the antimicrobial phytochemicals have MIC in range of $0.05-0.1 \%$ i.e., 0.5 to $1 \mathrm{mg} \mathrm{mL}^{-1}[2,3]$.

\section{Antimicrobial sensitivity assay}

Antimicrobial sensitivity of all bacterial strains for different herbal drugs and ampicillin was determined as described earlier using disc diffusion and agar well diffusion (for minimum inhibitory concentration, MIC) methods [8]. Before testing, strains were grown overnight in Mueller Hinton broth, MHB (BBL, Diffco), for non-fastidious organism and MHB with 5\% lysed sheep blood (LSB) for fastidious (Bordetella, Brucella, Campylobacter, Listeria, Pasteurella, Streptococcus) bacteria. The growth was adjusted with sterile phosphate buffer saline (PBS) to optical density $(590 \mathrm{~nm})$ of 0.1 before inoculating Mueller Hinton agar (MHA) or MHA-LSB plates through swabbing. Appropriate antibiotic discs were applied at 15-20 $\mathrm{mm}$ distance and ampicillin $(10 \mathrm{mg})$ discs (BBL, Diffco) were used as positive antibiotic control for disc diffusion method. For determining MIC, $140 \mathrm{~mm}$ plates containing 16 wells already sealed with $1 \%$ sterile agarose were swab inoculated. The central well received $50 \mu \mathrm{L}$ of sterile dimethyl sulphoxide (DMSO) and 1 to 15 number wells had suitably diluted herbal preparation in $50 \mu \mathrm{L}$ DMSO to dispense $1,2,4,8,16,32,64$, $128,256,512,1024,2048,4096,8192$ and $16384 \mu \mathrm{g}$ of the test extract or oil. For MIC plates were not inverted for first 4 hours of incubation. Plates were incubated aerobically for all but Brucella and Campylobacter strains which were incubated under $5 \% \mathrm{CO}_{2}$ pressure at $37^{\circ} \mathrm{C}$ for $24 \mathrm{~h}$. After incubation diameter of zone of inhibition around discs was measured in $\mathrm{mm}$. Any zone of growth inhibition around herbal discs was indicative of sensitivity of bacteria to the material in the disc while the well containing the least amount of extract or oil with visible zone of growth inhibition was taken as MIC of the drug. All the experiments were repeated to conformity. Interpretations for ampicillin sensitivity were made in accordance of CLSI guidelines [9].

Table 2: Source of bacteria and their sensitivity to different herbal antimicrobials tested using disc (containing $1 \mathrm{mg}$ of active ingredient/disc) diffusion assay on Mueller Hinton agar (MHA) for non-fastidious bacteria, MHA with lysed sheep blood (5\%) for fastidious bacteria (Bordetella, Brucella, Campylobacter, Listeria, Pasteurella, Streptococcus).

\begin{tabular}{|c|c|c|c|c|c|c|c|c|}
\hline \multicolumn{2}{|l|}{ Source (no. of strains) } & \multirow{2}{*}{$\begin{array}{l}\text { EOME } \\
107\end{array}$} & \multirow{2}{*}{\begin{tabular}{|l|} 
ACME \\
226 \\
\end{tabular}} & \multirow{2}{*}{$\begin{array}{l}\text { LGO } \\
254\end{array}$} & \multirow{2}{*}{$\begin{array}{l}\text { SWO } \\
225 \\
\end{array}$} & \multirow{2}{*}{\begin{tabular}{|l|} 
PO \\
254 \\
\end{tabular}} & \multirow{2}{*}{$\begin{array}{l}\text { ZRME } \\
248\end{array}$} & \multirow{2}{*}{$\begin{array}{l}\text { AO } \\
50\end{array}$} \\
\hline Axone, fermented soy- & Tested & & & & & & & \\
\hline beans $(254)$ & Sensitive & 60 & 101 & 132 & 125 & 123 & 53 & 11 \\
\hline \multirow{2}{*}{$\begin{array}{l}\text { Buffen, buffalo meat } \\
\text { (12) }\end{array}$} & Tested & NT & NT & 12 & 12 & 12 & NT & 12 \\
\hline & Sensitive & NT & NT & 7 & 12 & 6 & NT & 4 \\
\hline \multirow{2}{*}{$\begin{array}{l}\text { Chevon, goat meat } \\
\text { (32) }\end{array}$} & Tested & NT & NT & 32 & 32 & 32 & 32 & 32 \\
\hline & Sensitive & NT & NT & 15 & 29 & 22 & 6 & 5 \\
\hline \multirow[t]{2}{*}{ Buffalo milk (49) } & Tested & 15 & 14 & 49 & 40 & 45 & 5 & 44 \\
\hline & Sensitive & 6 & 6 & 16 & 13 & 9 & 1 & 6 \\
\hline \multirow{2}{*}{$\begin{array}{l}\text { Hands of food han- } \\
\text { dlers (14) }\end{array}$} & Tested & NT & NT & 14 & 14 & 14 & 14 & NT \\
\hline & Sensitive & NT & NT & 6 & 11 & 2 & 3 & NT \\
\hline \multirow{2}{*}{$\begin{array}{l}\text { Muffen, Mithun meat } \\
\text { (8) }\end{array}$} & Tested & 8 & 8 & 8 & 8 & 8 & 8 & 8 \\
\hline & Sensitive & 0 & 0 & 0 & 0 & 0 & 0 & 4 \\
\hline \multirow{2}{*}{$\begin{array}{l}\text { Fish, swabs from gills } \\
\text { (33) }\end{array}$} & Tested & NT & NT & 33 & 11 & 33 & NT & NT \\
\hline & Sensitive & NT & NT & 21 & 0 & 0 & NT & NT \\
\hline \multirow[t]{2}{*}{ Reference strains (62) } & Tested & 32 & 32 & 58 & 62 & 62 & 24 & 60 \\
\hline & Sensitive & 5 & 7 & 14 & 10 & 10 & 2 & 6 \\
\hline
\end{tabular}

NT, not tested; EOME, methanolic extract of Eupatorium odoratum; ACME, methanolic extract of Ageratum conyzoides; LGO, lemon grass (Cymbopogon citrartus) oil; SWO, sandalwood (Santalum album) oil; PO, patchouli (Pogostemon cablin) essential oil; ZRME, methanolic extract of seed carps of Zanthoxylus rhetsa, $\mathrm{AO}$, agarwood (Aquilaria crassna) oil. 


\section{Statistical analysis}

Correlation coefficient was calculated (MS Office Excel-7) to find out correlation between sensitivity (zone of inhibition in $\mathrm{mm}$ ) of test strains to different herbal antimicrobials and ampicillin discs. To estimate association between proportions of sensitive and resistant strains of microbes of different species, different genera and of different sources to herbal antimicrobials $\chi^{2}$ test was performed (MS Office Excel-2007). The statistical comparison was done for only those genera or sources where number $(\mathrm{n})$ of strains tested was $\geq 10$.

\section{Results}

On testing of 388 bacteria isolated from foods, 14 from food handlers and 62 reference strains belonging to more than 104 species of 33 genera (Tables 1 and 2) of Gram negative (194) bacteria (GNB) and Gram positive (270) bacteria (GPB) for their sensitivity to methanolic extract of Eupatorium odoratum (EOME), methanolic extract of Ageratum conyzoides (ACME), methanolic extract of Zanthoxylum rhetsa seed coat (ZRME), lemon grass (Cymbopogon citratus) oil (LGO), sandalwood (Santalum album) oil (SWO), patchouli (Pogostemon cablin) oil (PO) and agarwood (Aquilaria crassna) oil (AO) wide variation in antimicrobial activity of different herbs was evident. On the basis of oxidase reaction, test strains could be grouped in to four classes (Table 3 ) including oxidase +ve GNB (59), oxidase -ve GNB (135), oxidase +ve GPB (96), and oxidase -ve GPB (174).

The study revealed (Table 1) that sandalwood oil inhibited maximum number of strains $(50.5 \%)$ followed by LGO (45.9\%), EOME (43.8\%), ACME (40.4\%), PO (38\%), ZEME (19.6\%) and AO (17.5\%). However, 54.6\% bacteria were detected sensitive to ampicillin discs. In general, more of the ampicillin sensitive strains were also more often sensitive to $\operatorname{EOME}(\mathrm{p}, 0.05), \mathrm{ACME}(\mathrm{p}, 0.04), \mathrm{AO}$ and SWO (p, $0.03)$ than ampicillin resistant strains. However, difference was insignificant among the two groups for their sensitivity to LGO (p, 0.1), PO (p, 0.16) and ZRME (p, 0.64).

Although none of the herbal preparation tested had antimicrobial activity parallel to ampicillin, zone of inhibition induced by herbal antimicrobial discs was positively correlated with zone of inhibition induced by ampicillin discs. The correlation in growth inhibition with ampicillin could be defined as strong, positive and highly significant $(p, 0.01)$ for SWO, EOME and AME, moderately significant (p, 0.05) for $\mathrm{AO}$ and $\mathrm{LGO}$, and insignificant for $\mathrm{PO}$ and ZEME. Sandalwood oil (SWO) being the most effective antimicrobial photochemical (Table 1) inhibited growth of the maximum number of strains (50.5\%) followed by LGO (45.9\%), EOME (43.8\%), ACME (40.4\%), PO (38\%), ZEME (19.6\%) and $\mathrm{AO}(17.5 \%)$.

Bigger proportion of bacteria of foods of vegetable food (Axone) origin (Table 2) was sensitive to $\operatorname{EOME~(~} p, 0.009)$ and PO $(p, 0.0002)$ than bacteria from foods of animal origin or from food handlers. Bacteria on hands of food handlers were more often sensitive to LGO than those from muffen ( $p, 0.03)$; to SWO than those from reference, milk, fish and muffen ( $p, 0.01)$; but less sensitive to PO than the strains from buffen ( $p, 0.05)$, chevon ( $p, 0.01)$ and Axone ( $p, 0.01)$. Though agar wood oil was the least effective antimicrobial in the study, its activity was significantly more evident on isolates of muffen origin than strains of buffen $((p, 0.03)$ and chevon ( $p, 0.04)$ origin. However, more of the Staphylococcus strains of buffen $(\mathrm{p}, \leq 0.02)$ and chevon $(\mathrm{p}, \leq 0.03)$ origin was sensitive to SWO

Table 3: Gram staining and oxidase reaction in relation to sensitivity of bacteria of food origin to different herbal antimicrobials tested using disc (containing $1 \mathrm{mg}$ of active ingredient/disc) diffusion assay on Mueller Hinton agar (MHA) for non-fastidious bacteria, MHA with lysed sheep blood (5\%) for fastidious bacteria (Bordetella, Brucella, Campylobacter, Listeria, Pasteurella, Streptococcus).

\begin{tabular}{|c|c|c|c|c|c|c|c|c|}
\hline \multicolumn{2}{|c|}{ Oxidase production and Gram reaction } & \multirow{2}{*}{$\begin{array}{l}\text { EOME } \\
39\end{array}$} & \multirow{2}{*}{\begin{tabular}{|l|} 
ACME \\
87 \\
\end{tabular}} & \multirow{2}{*}{$\begin{array}{l}\text { LGO } \\
96\end{array}$} & \multirow{2}{*}{$\begin{array}{l}\text { SWO } \\
90\end{array}$} & \multirow{2}{*}{$\begin{aligned} \text { PO } \\
96\end{aligned}$} & \multirow{2}{*}{$\begin{array}{l}\text { ZRME } \\
89\end{array}$} & \multirow{2}{*}{\begin{tabular}{|l|} 
AO \\
22 \\
\end{tabular}} \\
\hline \multirow{3}{*}{ Oxidase +ve G +ve (96) } & Tested & & & & & & & \\
\hline & Sensitive & 33 & 59 & 83 & 80 & 75 & 37 & 10 \\
\hline & $\%$ sensitive & 84.6 & 67.8 & 86.5 & 88.9 & 78.1 & 41.6 & 45.5 \\
\hline \multirow{3}{*}{ Oxidase +ve G -ve (59) } & Tested & 22 & 38 & 59 & 34 & 59 & 27 & 20 \\
\hline & Sensitive & 4 & 26 & 35 & 14 & 24 & 9 & 3 \\
\hline & $\%$ sensitive & 18.2 & 68.4 & 59.3 & 41.2 & 40.7 & 33.3 & 15 \\
\hline \multirow{3}{*}{ Oxidase -ve G +ve (174) } & Tested & 72 & 83 & 170 & 171 & 172 & 139 & 102 \\
\hline & Sensitive & 33 & 22 & 65 & 106 & 66 & 13 & 18 \\
\hline & $\%$ sensitive & 45.8 & 26.5 & 38.2 & 62 & 38.4 & 9.4 & 17.6 \\
\hline \multirow{3}{*}{ Oxidase -ve G -ve (135) } & Tested & 29 & 74 & 135 & 109 & 133 & 76 & 62 \\
\hline & Sensitive & 1 & 7 & 28 & 4 & 10 & 6 & 5 \\
\hline & $\%$ sensitive & 3.4 & 9.5 & 20.7 & 3.7 & 7.5 & 7.9 & 8.1 \\
\hline
\end{tabular}

EOME, methanolic extract of Eupatorium odoratum; ACME, methanolic extract of Ageratum conyzoides; LGO, lemon grass (Cymbopogon citrartus) oil; SWO, sandalwood (Santalum album ) oil; PO, patchouli (Pogostemon cablin) essential oil; ZRME, methanolic extract of seed carps of Zanthoxylus rhetsa, AO, agarwood (Aquilaria crassna) oil; G +ve, Gram positive; G -ve, Gram negative. 
than strains isolated from Axone and milk. Chevon origin Staphylococcus strains were also more often sensitive to PO than those isolates from milk (, 0.05$)$ and from food handlers ( $p$, 0.01). For sensitivity of bacteria to other herbal antimicrobials, source of microbe was a significant determinant (Table 2).

Instead of source, genus of bacteria was more associated with sensitivity of bacteria to herbal antimicrobials (Tables 1 and 2). More of the Bacillus spp. strains were sensitive to all of the herbal preparations than strains of other bacteria $(\mathrm{p},<$ 0.01). Aeromonas spp. strains were more often sensitive to LGO $(p,<0.001)$ while Pseudomonas spp. strains to ACME $(p,<$ $0.01)$ than strains of other bacteria. Enterobacteriaceae strains in general showed more resistance to herbal antimicrobials than strains of any other families including Bacillaceae, Micrococaceae, Vibrionaceae and Pseudomonadaceae. More of the Pseudomonas spp. strains were sensitive to all (except EOME) herbal preparations tested than E. coli, Klebsiella, Proteus and Salmonella genus strains (,$\leq 0.05)$.

In general, more of the oxidase +ve strains were sensitive to herbal preparations tested than oxidase -ve strains ( $p$, $<0.01$ ). Similarly, more of the $G+$ ve strains were sensitive to herbal preparations than $G$-ve strains ( $p,<0.02)$, except insignificant difference in sensitivity of the two type of the strains to ZRME (p, 0.12). Among all four groups of bacteria on the basis of Gram's staining and oxidase production, $\mathrm{O}+\mathrm{ve}$ $\mathrm{G}+\mathrm{ve}$ bacteria were the most sensitive group $(\mathrm{p},<0.05)$ for all the preparations tested in the study barring a few exceptions (Table 3). Exception included almost equal sensitivity of $\mathrm{O}$ +ve $\mathrm{G}+$ ve and $\mathrm{O}$ +ve $\mathrm{G}$-ve strains to ZRME and ACME ( $p,>0.44)$. Strains showing $\mathrm{O}+\mathrm{ve} \mathrm{G}$-ve reaction were often more sensitive than $\mathrm{O}$-ve $\mathrm{G}$-ve strains $(\mathrm{p},<0.01)$ for all the preparations but almost equally sensitive to EOME and AO. Similarly, more of $\mathrm{O}$-ve $\mathrm{G}$ +ve strains were sensitive to herbal antimicrobial preparations tested than $\mathrm{O}$-ve $\mathrm{G}$-ve strains (p $<, 0.01$ ) but equally sensitive to $\mathrm{AO}$ and $\mathrm{ZRME}$.

The MIC for different herbal preparations varied for different strains (Table 4). For PO and SWO, it ranged from $1 \mu \mathrm{g} \mathrm{mL} \mathrm{m}^{-1}$ to $>16.384 \mathrm{mg} \mathrm{mL}^{-1}$, for LGO it ranged from 4 $\mu \mathrm{g} \mathrm{mL} \mathrm{mL}^{-1}$ to $>16.384 \mathrm{mg} \mathrm{mL}^{-1}$, for $\mathrm{AO}$ and $\mathrm{ZRME}$ it ranged from $8 \mu \mathrm{g} \mathrm{mL}^{-1}$ to $>16.384 \mathrm{mg} \mathrm{mL}^{-1}$, while for EOME and ACME it ranged from $16 \mu \mathrm{g} \mathrm{mL} \mathrm{m}^{-1}$ to $>16.384 \mathrm{mg} \mathrm{mL}^{-1}$. In terms of MIC, Salmonella strains were the most resistant strains (MIC never less than $640 \mu \mathrm{g} \mathrm{mL}^{-1}$ ) closely followed by Citrobacter, E. coli, and Klebsiella strains (MIC was always $\geq 340$ $\mu \mathrm{g} \mathrm{mL} \mathrm{mL}^{-1}$. Bacillus and Aeromonas spp. strains were the most sensitive ones, never had MIC $\leq 4.096 \mathrm{mg} \mathrm{mL}^{-1}$ for any of the herbal antimicrobial and Streptococcus was next sensitive genus $\left(\mathrm{MIC} \leq 8.192 \mathrm{mg} \mathrm{mL}^{-1}\right)$.

\section{Discussion}

Foods irrespective of their origin may contain several spoilage and many potentially pathogenic bacteria which limits consumer acceptability and safety for the foods. Moreover, additives in processed foods further add to the risk. Although many of the spices added in foods have antimicrobial activity $[4,5]$ they may also add to microbial load of the food being
Table 4: Minimum inhibitory concentration (MIC) of the herbal antimicrobials against bacteria isolated from foods and food handlers.

\begin{tabular}{|c|c|c|}
\hline $\begin{array}{l}\text { Name of } \\
\text { herbal } \\
\text { antimicrobial } \\
\text { Drug }\end{array}$ & 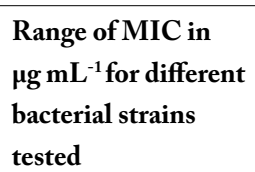 & $\begin{array}{l}\text { Five bacterial strains with the } \\
\text { least } \mathrm{MIC}\left(\mathrm{MIC} \text { in } \mu \mathrm{g} \mathrm{mL}^{-1}\right)\end{array}$ \\
\hline $\begin{array}{l}\text { Sandalwood } \\
\text { oil }\end{array}$ & 1 to more than 16384 & $\begin{array}{l}\text { Streptococcus pyogenese (1) } \\
\text { Pasteurella canis (1) } \\
\text { Pasteurella multocida (2) } \\
\text { Brucella abortus (8) } \\
\text { Salmonella enterica ser } \\
\text { Gallinarum (640) }\end{array}$ \\
\hline Patchouli oil & 1 to more than 16384 & $\begin{array}{l}\text { Streptococcus pyogenese (1) } \\
\text { Bacillus polymyxa (1) } \\
\text { Brucella abortus (2) } \\
\text { Bordetella bronchiseptica (2) } \\
\text { Staphylococcus aureus (4) }\end{array}$ \\
\hline Agarwood oil & 8 to more than 16384 & $\begin{array}{l}\text { Acinetobacter calcoaceticus (8) } \\
\text { Alcaligenes faecalis (8) } \\
\text { Bacillus subtilis (64) } \\
\text { Brucella abortus (128) } \\
\text { Streptococcus pyogenese (128) }\end{array}$ \\
\hline $\begin{array}{l}\text { Zanthoxylum } \\
\text { rhetsa oil }\end{array}$ & 8 to more than 16384 & $\begin{array}{l}\text { Bacillus pantothenticus (8) } \\
\text { Streptococcus aglactiae (8) } \\
\text { Streptococcus equi ssp. equisimilis } \\
\text { (8) } \\
\text { Proteus mirabilis (64) } \\
\text { Acinetibacter calcoaceticus (128) }\end{array}$ \\
\hline $\begin{array}{l}\text { Lemon grass } \\
\text { oil }\end{array}$ & 4 to more than 16384 & $\begin{array}{l}\text { Brucella abortus (4) } \\
\text { Bacillus pantothenticus (8) } \\
\text { Bacillus mycoides (8) } \\
\text { Aeromonas hydrophila (8) } \\
\text { Acinetibacter calcoaceticus (8) }\end{array}$ \\
\hline $\begin{array}{l}\text { Eupatorium } \\
\text { odoratum } \\
\text { methanolic } \\
\text { extract }\end{array}$ & 16 to more than 16384 & $\begin{array}{l}\text { Bacillus subtilis (16) } \\
\text { Burkholderia cepacia (64) } \\
\text { Streptococcus equi ssp. equisimilis } \\
\text { (64) } \\
\text { Bacillus mycoides (128) } \\
\text { Bacillus pantothenticus (256) }\end{array}$ \\
\hline $\begin{array}{l}\text { Ageratum } \\
\text { conyzoides } \\
\text { methanolic } \\
\text { extract }\end{array}$ & 16 to more than 16384 & $\begin{array}{l}\text { Streptococcus pyogenes (16) } \\
\text { Bacillus subtilis (32) } \\
\text { Burkholderia cepacia (64) } \\
\text { Streptococcus equi ssp. equisimilis } \\
\text { (64) } \\
\text { Staphylococcus aureus (64) }\end{array}$ \\
\hline
\end{tabular}

All resistant strains detected sensitive with disc diffusion assay had MIC < $1024 \mu \mathrm{g} \mathrm{mL} \mathrm{m}^{-1}$ while for resistant strains it varied from $1.024 \mathrm{mg} \mathrm{mL}-1$ to $16.384 \mathrm{mg} / \mathrm{mL}^{-1}$. Salmonella strains were the most resistant strains (in terms of MIC) in the study for most the preparations tested closely followed by Citrobacter, E. coli, and Klebsiella strains. Bacillus strains were the most sensitive ones, never had MIC $>4.096 \mathrm{mg} \mathrm{mL}^{-1}$ and Streptococcus was next sensitive genus.

loaded with bacteria [10-12]. In scenario of emergence of multiple drug resistant strains in different spheres including biotic and abiotic environment food are also not aloof of those. 
Studies have shown that being time tested herbal antimicrobials may be effective against bacteria including MDR strains [13] and thus are of potentially utility. Several studies have been conducted on efficacy of different herbs and herbal products on foodborne bacteria $[1,2]$ but being limited with the number of strains restrict the utility. Moreover, regional variation in microbial quality of foods, the microbiota composition and different herbs and spices used and their antimicrobial quality [14] necessitate elaborate regional studies on efficacy of herbs and herbal antimicrobials on the bacteria occurring in foods.

Sandalwood oil(SWO) was the mosteffective antimicrobial inhibiting the maximum number of strains (50.5\%) followed by LGO (45.9\%), EOME (43.8\%), ACME (40.4\%), PO (38\%), ZEME (19.6\%) and AO (17.5\%). However, none of the herbal preparation tested had antimicrobial activity parallel to ampicillin and observations are in concurrence to earlier observations on efficacy of herbal antimicrobials on microbial strains of different origin in India [7].

Zone of inhibition induced by SWO, EOME and AME, $\mathrm{AO}$ and LGO discs could positively correlate with zone of inhibition induced by ampicillin discs. The correlation indicated that similar mechanism of sensitivity/resistance might be operational in microbes for herbs and antibiotics as proposed earlier [3, 7]. However, more controlled studies are required to confirm the hypothesis.

Observations of more sensitivity of bacteria from Axone to $\operatorname{EOME}(p, 0.009)$ and $\mathrm{PO}(p, 0.0002)$ than bacteria isolated from foods of animal origin or from food handlers $(p, 0.013)$ are important. However, earlier studies have not made similar comparison; higher sensitivity of Axone origin strains than strains of animal origin has been reported [15-18]. Therefore, it might be attributed to carryover effect on resistant strains of bacteria from animals to their products and then to the food handlers or transfer of drug resistant bacteria from hands of food handlers to animal products $[19,20]$.

Antimicrobial activity of agar oil, the least effective antimicrobial in the study, varied according to source of the bacteria tested. Significantly more of the bacteria of muffen origin than those of buffen (p, 0.03) and chevon (p, 0.04) origin were sensitive to agar oil. The observation cannot be explained on the basis of limited number of observations in the study. However, sensitivity of many of the Bacillus, Staphylococcus and Streptococcus but not of $E$. coli strains to AO observed in the study is in concurrence to earlier studies revealing the same fact [21].

The study indicated that instead of source of bacteria their genus was more important determinant of their sensitivity to many of the herbal preparations. More of the Bacillus spp. strains were sensitive to herbal preparations $(p,<0.01)$ than strains of other bacteria and observations are in concurrence to earlier studies [15-18, 21, 22]. More sensitivity of Aeromonas strains to LGO is also similar as reported earlier [16]. Many (95.6\%) more of the Pseudomonas spp. strains were sensitive ACME than strains of other bacteria. Though interesting, it is in contrast to earlier observations reporting Pseudomonas as the most resistant bacteria tested against Ageratum oil [23]. It might be due to several reasons viz., regional effect, bacteria from different regions may differ in their sensitivity pattern $[9,24]$, difference in the source of herb etc. More common occurrence of resistance in Enterobacteriaceae strains to herbal antimicrobials preparations tested is in concurrence to earlier observations on herbal antimicrobials [15-18, 21, 22, 25]. Sensitivity of oxidase +ve strains to herbal antimicrobials tested in the study was an important observations as many of the deadly pathogens of animal are oxidase positive including Aeromonas, Bacillus, Brucella, Pasteurella, Pseudomonas, Burkbolderia and Campylobacter spp. strains [26, 27]. However, the observation may be skewed due to proportionately high level of sensitivity of Brucella (4), Bacillus (94) and Pseudomonas (30) strains constituting $>82 \%$ of the total oxidase positive strains in the study. Similar to oxidase -ve $G$-ve strains, some of the oxidase positive groups including Aeromonas and Campylobacter spp. strains were rarely sensitive to herbal antimicrobial in the study. Though cannot be deduced from the study it might be associated with microhabitat of the potential pathogens, the pathogens affecting system other than gastrointestinal tract might be more prone for killing by the herbal preparations.

The MIC for different herbal preparations varied for different strains (Table 4) from $1 \mu \mathrm{g} \mathrm{mL} \mathrm{mL}^{-1}$ to $>16.384 \mathrm{mg}$ $\mathrm{mL}^{-1}$. Variation in MIC observed under the study appeared to be similar phenomenon as observed for antibiotics $[8,9]$. In the study MIC of herbal antimicrobials was the maximum for Salmonella, Citrobacter, E. coli, and Klebsiella strains, all the members of Enterobacteriaceae. High level of antimicrobial drug resistance in Enterobacteriaceae member has been frequently reported all over the world [9].

Observations revealed that for herbal antimicrobials (methanolic extract of Eupatorium odoratum Ageratum conyzoides, Zanthoxylum rhetsa, and essential oils of Cymbopogon citrates, Pogostemon cablin, Santalum album wood and Aquilaria crassna wood) in general, Pseudomonas and Bacillus strains were more often sensitive little or not affected by the source of isolation. However, it was evident that more of the strains of Axone (fermented soybean) origin were sensitive to all the herbs tested than the strains isolated from foods of animal origin. To understand the role of oxidase production in sensitivity of bacteria to herbal antimicrobials more organized studies are required considering the zoonotic potential of oxidase positive bacteria including large and comparable number of strains of Aeromonas, Bacillus, Brucella, Pasteurella, Pseudomonas, Burkbolderia and Campylobacter species. The study further reveals that herbal antimicrobials, being edible and acceptable since ages, can be an option for use in foods to control spoilage as most of the Pseudomonas and Bacillus strains (common bacteria associated with food spoilage) were inhibited by herbal antimicrobials. However, the choice of herbal antimicrobial may depend on type of microbe causing the problem in the specific food unit or the region.

\section{Acknowledgements}

Authors are thankful to the Director and Joint Director (Research) for permitting to undertake the study. Authors are thankful to in-charges of Brucella, Campylobacter, Salmonella 
and other specific pathogen laboratories of the Institute for providing the reference cultures. We also thanks to Dr. RK Singh, In-charge KVK, Phek, Nagaland, for helping in collection of fresh leaves of Eupatorium odoratum, Ageratum conyzoides, and seeds of Zanthoxylum rhetsa. Authors also thank supporting staff of Epidemiology laboratory (Mr. HC Joshi and Laikur Rahman Khan) for their untiring support throughout the study.

\section{Conflict of Interest}

There is no conflict of interest pertaining to this manuscript.

\section{Authors Contribution}

All the three authors planned and carried out the research work, data analysis and manuscript draft was done by the first author (BRS), $2^{\text {nd }}(\mathrm{DKS})$ and $3^{\text {rd }}$ author (VKOR) rechecked the analysed data and manuscript for correctness.

\section{References}

1. Tiwari BK, Valdramidis VP, Bourke P, Cullen P. 2011. Application of plant based antimicrobials in food preservation. In: Rai M, Chikindas M (eds) Natural Antimicrobials in Food Safety and Quality. CAB International, Wallingford, UK, pp 204-223.

2. Tajkarimi M, Ibrahim SA. 2012. Phytochemicals as antimicrobial food preservatives. In: Patra AK (eds), Dietary Phytochemicals and Microbes. Springer, Netherlands, pp 207-235.

3. Vadhana P, Singh BR, Bhardwaj M, Singh SV. 2015. Emergence of herbal antimicrobial drug resistance in clinical bacterial isolates. Pharm Anal Acta 6: 434. doi: 10.4172/21532435.1000434.

4. Chopra RN, Nayar SL, Chopra CI. 1956. Glossary of Indian medicinal plants. CSIR, New Delhi, India.

5. Agarwal SS, Tamrakar BP, Paridhavi M. 2005. Clinically useful herbal drugs. Ahuja Book Company Pvt. Ltd., New Delhi, India.

6. Singh BR. 2009. Labtop for microbiology laboratory. Lambert Academic Publishing, AG \& Co. KG, Berlin, Germany.

7. Singh BR. 2014. Multiple-herbal-antimicrobial-resistance (MHAR) in microbes of animals, birds, fish, food, lizard and water origin. In: Proceedings of International Conference and $28^{\text {th }}$ Annual Convention of IAVMI-2014 on "Challenges and Opportunities in Animal Health at the Face of Globalization and Climate Change". Department of Veterinary Microbiology and Immunology, DUVASU, Mathura, India, pp 26-29.

8. Singh BR. 2013. Antimicrobial sensitivity assay and antimicrobial chemotherapy in Animals: a practical approach. In: Singh BR, Somvanshi R (eds) Diseases of Animals: Diagnosis and Management, Indian Veterinary Research Institute, Izatnagar, India, pp 7-31.

9. Clinical and Laboratory Standards Institute (CLSI). 2015. Performance standards for antimicrobial disk susceptibility tests, $12^{\text {th }}$ edition (M02-A12). CLSI, Wayne, Pennsylvania, USA.

10. Drew AK, Myers SP.1997. Safety issues in herbal medicine: implications for the health professions. Med J Aust 166(10): 538-541.
11. Ogunshe AAO, Kolajo TT. 2006. In vitro phenotypic antibiotic resistance in bacterial flora of some indigenous orally consumed herbal medications in Nigeria. JRTPH 5: 9-15.

12. Brown JC, Jiang X. 2008. Prevalence of antibiotic-resistant bacteria in herbal products.J Food Prot 71(7): 1486-1490.

13. Nostro A. 2006. Activity of plant extracts and plant-derived compounds against drug-resistant microorganisms. In: Ahmad I, Aqil F, Owais M (eds) Modern Phyto Medicine, Wiley-VCH, Weinheim, Germany, pp 199-231. doi: 10.1002/9783527609987

14. Cimanga K, Kambu K, Tona L, Apers S, De Bruyne T, et al. 2002. Correlation between chemical composition and antibacterial activity of essential oils of some aromatic medicinal plants growing in the Democratic Republic of Congo. J Ethnopharmacol 79(2): 213-220. doi: 10.1016/S0378-8741(01)00384-1

15. Singh BR, Singh V, Singh RK, Toppo S, Haque N, et al. 2011. Antimicrobial effect of Artemisia vulgaris essential oil. Natural Products: An Indian J 7: 5-12. doi: 10.5958/j.0975-4261.4.2.003

16. Singh BR, Singh V, Singh RK, Ebibeni N. 2011. Antimicrobial activity of lemongrass (Cymbopogon citratus) oil against microbes of environmental, clinical and food origin. Int Res J Pharm Pharmacol 1(9): 228-236.

17. Singh BR, Singh V, Singh RK, Toppo S, Haque N, et al. 2012. Antimicrobial activity on common pathogens in essential oil of aerial parts of Selinum wallichianum. Natural Products: An Indian J8: 233-237.

18. Singh BR, Singh V, Singh RK, Toppo S, Haque N, et al. 2012. Comparative evaluation of antimicrobial effect of Artemisia vulgaris essential oils extracted from fresh and dried herb. Med Plant 4: 76-82. doi: 10.5958/j.0975-4261.4.2.003

19. Humphrey T, Jorgensen F. 2006. Pathogens on meat and infection in animals - establishing a relationship using Campylobacter and Salmonella as examples. Meat Sci 74(1): 89-97. doi: 10.1016/j.meatsci.2006.04.026

20. Bhardwaj M, Singh BR, Murugan MS, Prasannavadhana, Dubey S. 2015. Emergence of carbapenemase producing pathogens in animals. Pharm Anal Acta 6(6): 379. doi: 10.4172/2153-2435.1000379.

21. Chen H, Yang Y, Xue J, Wei J, Zhang Z, et al. 2011. Comparison of compositions and antimicrobial activities of essential oils from chemically stimulated agarwood, wild agarwood and healthy Aquilaria sinensis (Lour.) Gilg trees. Molecules 16(6): 4884-4896. doi: 10.3390/ molecules16064884

22. Singh BR. 2013. Evaluation of antibacterial activity of sage (Salvia officinalis) oil on veterinary clinical isolates of bacteria. Noto-are Med. 15341289 .

23. Dayie NT, Newman MJ, Ayitey-Smith E, Tayman F. 2008. Screening for antimicrobial activity of Ageratum conyzoides: a pharmacomicrobiological approach. Internet Journal of Pharmacology 5(2): 1-6.

24. Singh BR. 2011. Drug resistant bacteria in the environment: In: Garg SR (ed) Environmental Security: Human and Animal Health, $1^{\text {st }}$ edition. IBDC Publishers, Lucknow, India, pp 313-326.

25. Garg P, Grewal A. 2015. In vitro antibacterial activity of Ageratum conyzoides L (Asteraceae). World J Pharmacy Pharmaceut Sci 4(7): 893897.

26. Carter GR. 1975. Diagnostic procedures in veterinary microbiology, $2^{\text {nd }}$ edition. Charles C Thomas Publishers, Springfield, USA.

27. McVey DS, Kennedy M, Chengappa MM. 2013. Veterinary microbiology, $3^{\text {rd }}$ edition. Wiley-Blackwell, Oxford, UK. 